The Cryosphere Discuss., doi:10.5194/tc-2017-55, 2017

Manuscript under review for journal The Cryosphere

Discussion started: 3 May 2017

(c) Author(s) 2017. CC-BY 3.0 License.

\title{
Measured and Modeled Snow Cover Properties across the Greenland
}

\section{Ice Sheet}

Sascha Bellaire ${ }^{1}$, Martin Proksch ${ }^{1}$, Martin Schneebeli ${ }^{1}$, Masashi Niwano ${ }^{2}$, Konrad Steffen ${ }^{3,4}$

${ }^{1}$ WSL Institute for Snow and Avalanche Research SLF, Davos, Switzerland

${ }^{2}$ Meteorological Research Institute, Japan Meteorological Agency, Tsukuba, Japan

${ }^{3}$ Swiss Federal Institute for Forest, Snow and Landscape Research WSL, Birmensdorf, Switzerland

${ }^{4}$ Institute for Atmospheric and Climate Science, ETH Zurich, Switzerland

Correspondence to: Sascha Bellaire (bellaire@slf.ch), Martin Schneebeli (schneebeli@slf.ch)

\begin{abstract}
The Greenland ice sheet (GrIS) is known to be contributing to sea level rise in a warming climate. The snow cover on the ice sheet is the direct link between a potentially warmer atmosphere and the ice itself. However, little is known about the microstructure and especially about the spatial and temporal variability of the snow cover, except from indirect evidence from remote sensing. The detailed snowpack stratigraphy is relevant for processes such as the albedo feedback, water infiltration and firn densification. During a field campaign in 2015, spatially distributed snow observations of the GrIS were gathered at stations belonging to the Greenland Climate Network (GC-Net). High-resolution snow profiles of density, specific surface area and hardness were measured. Hardness was measured with the SnowMicroPen, which was also used to assess the spatial variability of the snow density with depth. The snow cover model SNOWPACK was forced with reanalysis data from the model NHM-SMAP. The measured mean density of the upper snow cover was in good agreement with the simulations using constant densities for snow accumulation, i.e. new snow, depending on the geographical location on the GrIS. However, the observed stratigraphy in terms of density and SSA could not be reproduced. We found that for a one-dimensional snowpack model it is difficult to parameterize for snowpacks undergoing multiple erosion and redeposition events, as is typical for the GrIS and other perennial polar snowpacks. This limitation may be a drawback to understanding past and future changes of the snow, and the associated processes.
\end{abstract}

Keywords: Greenland ice sheet, snow cover modeling, density, specific surface area, SNOWPACK, NHM-SMAP 
The Cryosphere Discuss., doi:10.5194/tc-2017-55, 2017

Manuscript under review for journal The Cryosphere

Discussion started: 3 May 2017

(c) Author(s) 2017. CC-BY 3.0 License.

\section{Introduction}

The Greenland ice sheet (GrIS) contributed around $8 \mathrm{~mm}$ to global sea level rise in the period from 1992 to 2011 (e.g. van den Broke et al., 2009; Shepard et al., 2012). The rate of melt and mass loss of the GrIS is increasing (Shepard et al., 2012, Orsi et al., 2017) and projected to further increase in the future (IPCC, 2014). Observed mass loss is largest at the coastal areas due to

5 calving processes with a receding ice edge (e.g. Rignot and Kanagaratnam, 2006; van den Broeke, 2009). Recently, extreme melt events have been observed in the Greenland interior (e.g. Nghiem et al., 2012; Niwano et al., 2015), indicating that significant changes in the energy balance are now possible in the accumulation area of the GrIS. The fringe around the equilibrium line is the most affected area, with subsequent additional ice melt (Steger et al., 2017). Benson (1960) studied the stratigraphy of the snowpack in detail during several traverses. His study provided the emphasis for the work presented here,

10 i.e. whether past warming affects metamorphism and snowpack stratigraphy. To this end, a snowpack simulation must be able to reproduce the current state, which is the topic of this article.

The snow cover in Greenland and its mechanical and structural properties are important for achieving a more detailed understanding of the firn densification and for improving larger-scale surface mass balance models (e.g. RACMO; van Meijgaard et al., 2008; MAR; Fettweis et al., 2007). Furthermore, in order to estimate the mass loss or gain due to melting or snow redistribution, the snow cover density and the change in specific surface area (SSA) are both required. Infiltration is largely affected by the stratigraphy and occurs mostly by preferential flow paths. The stratigraphy is therefore very relevant (Wever et al., 2015; Avanzi et al., 2017). An equally important factor is the albedo feedback, which is mainly a result of the rate of the reduction in SSA (Box et al., 2012).

Typically, due to the sparse availability of meteorological data, reanalysis data (e.g. Franco et al., 2012) or satellite products (e.g. Tedesco et al., 2012), or a combination of both (e.g. van Tricht et al., 2016), are used to model the GrIS snow cover and, hence, the surface energy and mass balance. The temporal resolution of these data is typically between 6 hours to 1 day, which implies that detailed changes in physical conditions of the GrIS snow are not fully captured.

Reanalysis products typically use simplified snow schemes, which lack the high resolution and degree of detail of snow cover models such as Crocus (Vionnet et al., 2012) or SNOWPACK (Bartelt and Lehning, 2002; Lehning et al., 2002a, b). Recently, van Tricht et al. (2016) used SNOWPACK to investigate the effect of clouds on the meltwater runoff on the GrIS. A detailed physical representation of the snow cover overlying the GrIS is in this respect indispensable to achieving a better understanding of the GrIS, in particular in a future warming climate.

Therefore, the main objectives of this study were modeling the present state of the GrIS overlaying snow cover in terms of density and stratigraphy. Simulations were carried out using the physically based snow cover model SNOWPACK forced with 
The Cryosphere Discuss., doi:10.5194/tc-2017-55, 2017

Manuscript under review for journal The Cryosphere

Discussion started: 3 May 2017

(c) Author(s) 2017. CC-BY 3.0 License.

\section{Data and Methods}

\subsection{NHM-SMAP}

For this study, we used high-resolution $(5 \mathrm{~km})$ atmospheric reanalysis data generated by dynamically downscaling the Japanese Meteorological Agency's (JMA) latest reanalysis data, JRA-55 (the Japanese 55-year reanalysis; Kobayashi et al., 2015), with the JMA's operational nonhydrostatic atmospheric model, JMA-NHM (Saito et al., 2006), between 2010 and 2015. JMANHM has been used extensively for short-term weather forecasts on the GrIS to support field campaigns (Hashimoto et al., 2017), and its good performance on the GrIS has been demonstrated. Energy exchanges between the atmosphere and the snow/ice surfaces are calculated by a boundary-layer scheme implemented in the physical snow cover model SMAP (Niwano et al., 2012). The model domain in the present study covers the entire GrIS, and is the same as that documented by Hashimoto et al. (2017). This dataset will here on be referred to as NHM-SMAP.

Concerning the model setting of JMA-NHM, we followed Hashimoto et al. (2017). In addition to a single-moment scheme which only predicts the mixing ratio of particles of liquid hydrometeors, i.e. cloud water and rain - a detailed double-moment bulk cloud microphysics scheme was used to predict both the mixing ratio and concentration of particles of solid hydrometeors, i.e. cloud ice, snow, and graupel. A cumulus parametrization scheme was not used.

15 The NHM-SMAP model calculations were conducted using the so-called 'weather forecast mode'. This means that atmospheric profiles were initiated daily at 18 UTC using JRA-55 and simulations with a lead time of 30 hours were performed accordingly. Considering the model spin-up, results for the first 6 hours were neglected. As a result, hourly atmospheric data from 00 to 23 UTC were created daily. The surface meteorological properties provided by NHM-SMAP include precipitation, incoming shortwave and longwave radiation, cloud fraction, surface pressure, $2 \mathrm{~m}$ air temperature, $2 \mathrm{~m}$ relative humidity with respect to water - as well as the $2 \mathrm{~m}$ wind speed. The time series of meteorological NHM-SMAP data were extracted at stations of the Greenland Climate Network (GC-Net; Steffen and Box, 2001; Fig. 1) using the nearest-neighbor grid cell.

\subsection{Greenland Climate Network}

In order to assess the performance of NHM-SMAP, we compared the simulated air temperature, wind speed and incoming shortwave radiation with the measured (GC-Net) values. For comparison, we used hourly data from the Summit station between September 2010 and May 2015. Air temperature and wind speed were taken from the upper level sensors, namely the Type-E thermocouple for the air temperature and the RM Young 05103 for wind speed. Incoming shortwave radiation was measured with the LI-COR Photodiode. Further details on the GC-Net stations as well as data quality checks are provided by Steffen and Box (2001) and Box and Steffen (2000). 
The Cryosphere Discuss., doi:10.5194/tc-2017-55, 2017

Manuscript under review for journal The Cryosphere

Discussion started: 3 May 2017

(c) Author(s) 2017. CC-BY 3.0 License.

\subsection{SNOWPACK}

The snow cover model SNOWPACK (Bartelt et al., 2002; Lehning et al., 2002a, b; version 3.4.0) was forced with meteorological reanalysis data provided by NHM-SMAP. SNOWPACK can be driven using various combinations of input parameters. We chose to force SNOWPACK using incoming shortwave and longwave radiation, as well as liquid precipitation

5 along with air temperature, relative humidity and wind speed. Note that relative humidity in NHM-SMAP is calculated in relation to water and was corrected with respect to ice according to:

$R H_{\text {ice }}=\frac{e_{w}}{e_{i}} \times R H_{w a t e r}$,

with $\mathrm{RH}_{\text {ice }}$ as the relative humidity over ice and $\mathrm{RH}_{\text {water }}$ as the relative humidity over water. $\mathrm{e}_{\mathrm{w}}$ and $\mathrm{e}_{\mathrm{i}}$ denote the saturation vapour pressure over water and ice, respectively, and are defined as:

$e_{w}=611.2 \cdot e^{\frac{17.62 \cdot T}{243.12+T}} ; \quad e_{i}=611.2 \cdot e^{\frac{22.46 \cdot T}{272.62+T}}$,

with air temperature, T, given by NHM-SMAP.

For each location, SNOWPACK simulations were obtained for a 5-year time period between September 2010 and September 2015. SNOWPACK simulations were initiated in September 2010 using a snow profile with a uniform snow layer of $10 \mathrm{~m}$ with a density of $500 \mathrm{~kg} \mathrm{~m}^{-3}$ and a temperature corresponding to the average air temperature of the aforementioned time period as a starting point.

SNOWPACK can be used in different modes, namely 'research' (default), 'Japan' or 'Antarctica'. The various modes use different default settings or parameterizations. Although an 'Antarctica' mode exists in which snow deposition processes are likely to be comparable to the driving processes of snow cover evolution on the GrIS, we nevertheless chose to use the 'research' version of SNOWPACK. This is because the 'Antarctica' version (Groot-Zwaaftink et al., 2013) was calibrated for

20 a specific time period, i.e. the duration of the Antarctic campaign, and was not developed to be used for a longer time period, i.e. several years.

In the 'research' mode, SNOWPACK estimates the density of new snow during precipitation events based on the current meteorological conditions (Schmucki et al., 2014). However, this new snow density parameterization was obtained using density observations and meteorological conditions from an experimental site above Davos, Switzerland (Eastern Swiss Alps), and is therefore not suitable for an Arctic environment. Therefore, we ran SNOWPACK simulations using constant new snow densities of $300 \mathrm{~kg} \mathrm{~m}^{-3}, 325 \mathrm{~kg} \mathrm{~m}^{-3}$ and $350 \mathrm{~kg} \mathrm{~m}^{-3}$. These high values were chosen to reflect that snow precipitation almost always occurs under windy conditions, which leads to a very rapid diminution and a high packing density. This means new snow is added subsequently according to the liquid precipitation amounts provided by NHM-SMAP and the corresponding new snow density. SNOWPACK uses a static threshold of $+1.2{ }^{\circ} \mathrm{C}$, below which precipitation falls as snow and above which it falls as rain. 
The Cryosphere Discuss., doi:10.5194/tc-2017-55, 2017

Manuscript under review for journal The Cryosphere

Discussion started: 3 May 2017

(c) Author(s) 2017. CC-BY 3.0 License.

For each time step, SNOWPACK provides profiles of the optical equivalent diameter - an objective quantification for grain size - which can be used to calculate the SSA $\left(\mathrm{m}^{2} \mathrm{~kg}^{-1}\right)$ according to Gergely et al. (2014).

\subsection{Field Measurements}

Field data were gathered during a field campaign in May 2015 across the GrIS. Stations of the GC-Net (Steffen and Box, 2001)

5 were frequented in order to conduct various snow cover observations. These observations comprised standard manual snow profiles, including density using a density cutter (Proksch et al., 2016), as well as snow temperature profiles. Resistance profiles were measured using the SnowMicroPen (SMP; Schneebeli and Johnson, 1998) and snow samples were taken for on-site analysis of SSA using the IceCube (Gallet et al., 2009). In addition, cast snow samples were taken at Summit and analyzed using micro-computed tomography (micro-CT).

10 For this study, we focused on density profiles derived from the SMP signal (Proksch et al., 2015) as well as SSA measured with IceCube. A comparison of density observed with the density cutter and derived from the SMP signal is shown in Figure 2. A minimum number of 5 and a maximum number of 80 SMP profiles (see Fig. 8) were taken at the corresponding locations. The depth of the SMP profiles, i.e. down from the surface, ranged between $30 \mathrm{~cm}$ and the maximum depth of $200 \mathrm{~cm}$, with a median of $90 \mathrm{~cm}$.

15 SSA profiles were taken at 6 locations, namely Humboldt, NASA-E, South-Dome, Summit, Swiss Camp and TRV-1. Profiles were taken to a minimum depth of $105 \mathrm{~cm}$ and to a maximum depth of $120 \mathrm{~cm}$, depending on the location (median $=115 \mathrm{~cm}$ ). Only one SSA profile was taken at each corresponding location due to time constraints. Snow samples at Summit were taken down to a depth of about $140 \mathrm{~cm}$ and were analyzed using micro-CT with regard to density and SSA.

For the comparison of the modeled density (NHM-SMAP-SNOWPACK) and measured density (SMP), an average density was calculated by first averaging all available SMP profiles for each individual location and then calculating the mean density of the resulting profile. Similarly, a mean SSA was calculated by averaging the available profile at each site. In the following, we refer to SNOWPACK simulations forced with NHM-SMAP reanalysis data as NHM-SNOWPACK

\section{Results}

\subsection{Comparison of GC-Net and NHM-SMAP}

25 A comparison of the hourly measured (GC-Net) air temperature, wind speed and incoming shortwave radiation with the NHMSMAP equivalents for the Summit station is presented in Figure 3. In general, the observation and reanalysis data are in fair agreement, with coefficients of determination $\left(\mathrm{R}^{2}\right)$ being 0.89 for air temperature, 0.49 for wind speed and 0.84 for the incoming shortwave radiation. Intercepts of a simple linear regression for air temperature, wind speed and shortwave radiation were calculated as $-1.1,-0.4$ and 7.8. The corresponding slopes were $1.2,0.8$ and 1.1, respectively. NHM-SMAP tended to be 
The Cryosphere Discuss., doi:10.5194/tc-2017-55, 2017

Manuscript under review for journal The Cryosphere

Discussion started: 3 May 2017

(c) Author(s) 2017. CC-BY 3.0 License.

too warm with a mean error (ME) and a mean absolute error (MAE) of $5.7^{\circ} \mathrm{C}$ and $6.0^{\circ} \mathrm{C}$, respectively. Measured and modeled values deviated strongly below $-35^{\circ} \mathrm{C}$. It is possible that NHM-SMAP underestimates atmospheric inversion and the stability of the air. Furthermore, the wind speed tended to be overestimated $\left(\mathrm{ME}=1.2 \mathrm{~m} \mathrm{~s}^{-1}\right.$; MAE $=1.9 \mathrm{~m} \mathrm{~s}^{-1}$ ) and the incoming shortwave radiation underestimated $\left(\mathrm{ME}=-17.9 \mathrm{~W} \mathrm{~m}^{-2} ; \mathrm{MAE}=48.9\right)$. The higher modeled wind speed could be a reason for the generally too high air temperature in NHM-SMAP.

\subsection{NHM-SMAP Reanalysis}

A comparison of NHM-SMAP reanalysis data for 14 locations of the GC-Net is presented in Figure 4. Hourly NHM-SMAP 2 $\mathrm{m}$ air temperature, wind speed and incoming shortwave radiation from NHM-SMAP are shown. The stations are sorted (left to right) by decreasing latitude. In general, NHM-SMAP $2 \mathrm{~m}$ air temperature seems to be homogenous over the GrIS and variances can be explained by the elevation difference between the individual stations. For example, as the highest station, Summit (3,254 m a.s.1.) shows the coldest median temperature compared to Swiss Camp, the lowest station (1,149 $\mathrm{m}$ a.s.1). The NHM-SMAP $2 \mathrm{~m}$ wind speed also tends to be homogenous across the GrIS, with a median speed of about $5 \mathrm{~m} \mathrm{~s}^{-2}$. However, the maximum wind speeds tend to increase with decreasing latitude. A similar pattern was found for the incoming shortwave radiation (NHM-SMAP), which also showed increased median and maximum values with decreasing latitude.

15 The yearly precipitation totals (NHM-SMAP) between July 2012 and July 2015, i.e. over 3 years, are summarized in Table 1. Precipitation totals were calculated from July to June of each year. The greatest yearly precipitation sum was recorded at South Dome $\left(1,145 \mathrm{~mm} \mathrm{y}^{-1}\right)$ and the lowest sum $\left(69.4 \mathrm{~mm} \mathrm{y}^{-1}\right)$ at NASA-E. The maximum hourly precipitation amounts occurred at Swiss Camp $(25.6 \mathrm{~mm})$ and the least precipitation on an hourly basis was recorded at NASA-E $(2.1 \mathrm{~mm})$. The median yearly precipitation across the GrIS was found to be $328 \mathrm{~mm} \mathrm{y}^{-1}$.

20 A simple linear regression for yearly precipitation amounts using latitude as a predictor (Fig. 5) shows that almost $75 \%$ of the variation in the yearly totals can be explained by the latitude $\left(R^{2}=0.74\right.$; intercept $=4933$; coef. latitude $\left.=-61.5\right)$. Subsequently adding longitude $\left(\mathrm{R}^{2}=0.90\right.$; intercept $=4424$; coef. latitude $=-65.1$; coef. longitude $\left.=17.1\right)$ and elevation $\left(\mathrm{R}^{2}=0.94\right.$; intercept $=5085$; coef. latitude $=-66.4$; coef. longitude $=12.8$; coef. elevation $=-0.16)$ as predictors shows that the yearly variations can be explained by the geographical location in $90 \%$ and $94 \%$, respectively.

\subsection{Comparison of Observations and Simulations}

\subsubsection{Density}

The comparison of observed (SMP) and simulated (NHM-SNOWPACK) mean density is shown in Figure 6. The best results in the simulations were obtained using different constant densities for new snow events depending on the geographical location of the station of interest. As is depicted in Figure 1, $300 \mathrm{~kg} \mathrm{~m}^{-3}$ was used for all stations north of Summit, $325 \mathrm{~kg} \mathrm{~m}^{-3}$ for the 
The Cryosphere Discuss., doi:10.5194/tc-2017-55, 2017

Manuscript under review for journal The Cryosphere

Discussion started: 3 May 2017

(c) Author(s) 2017. CC-BY 3.0 License.

Summit and Crawford Point stations, and $350 \mathrm{~kg} \mathrm{~m}^{-3}$ for all remaining stations south of Crawford Point. The MAE was found to be $4 \mathrm{~kg} \mathrm{~m}^{-3}$ and the ME was $-1.0 \mathrm{~kg} \mathrm{~m}^{-3}$, indicating a very minor underestimation of the mean density. Although the mean simulated values are in good agreement with the observations, the simulations failed to reproduce the detailed observed stratigraphy (Fig. 8).

\section{$5 \quad$ 3.3.2 Specific Surface Area}

The SSA was measured using IceCube at 6 locations across the GrIS. The comparison of observed and simulated SSA is shown in Figure 7. The simulation systematically underestimated the observed (IceCube) mean SSA (ME $=-6.7 \mathrm{~m}^{2} \mathrm{~kg}^{-1}$ ). The mean SSA derived by micro-CT was in good agreement with the simulation. However, as shown in Figure 8, the simulated SSA tended to be underestimated in the upper part $(<60 \mathrm{~cm})$ and overestimated in the lower part of the profile $(>60 \mathrm{~cm})$. An SSA profile derived from micro-CT measurements is only available for Summit.

\subsubsection{Accumulation Depth}

In July 2012, the GrIS experienced an island-wide surface-melting event forming a melt-freeze crust, which was subsequently buried. During the 2015 field campaign this melt-freeze crust was detected using the SMP at 6 locations across the GrIS. The depth of this melt-freeze crust varied between $1.1 \mathrm{~m}$ and $1.8 \mathrm{~m}$ (median $=1.5 \mathrm{~m}$ ). The SMP used can only measure down to a maximum depth of about $2 \mathrm{~m}$, and consequently the melt-freeze crust could only be detected down to that depth.

We compared the observed depths of the melt-freeze crust to the simulated depth (Fig. 9). The depths were found to be in fair agreement with the observations. The MAE was $0.29 \mathrm{~m}(\mathrm{ME}=0.26)$, representing a general overestimation of accumulation. The largest deviation from the observation was about $0.7 \mathrm{~m}$, which was found for the NEEM station, i.e. $0.7 \mathrm{~m}$ too much snow depth above the 2012 melt-freeze crust.

\section{Discussion}

We compared meteorological reanalysis data (NHM-SMAP), specifically air temperature, wind speed and incoming shortwave radiation, with their corresponding measured (GC-Net) values. Although measurements and reanalysis were found to be in reasonable agreement (Fig. 2), differences remained to a certain extent (see section 3.1). The stations of the GC-Net are subject to extreme conditions of subzero temperatures and wind exposure. Therefore, sensors are sometimes covered with rime and,

25 although an automatic data quality check is applied, a certain unquantifiable error remains. A comparison with high-quality data from Summit station, for example, would allow a better quantification of the errors of the reanalysis data. However, the reanalysis data at Summit was found to be in fair agreement with literature values using high-quality data (e.g. Cullen and Steffen, 2001). 
The Cryosphere Discuss., doi:10.5194/tc-2017-55, 2017

Manuscript under review for journal The Cryosphere

Discussion started: 3 May 2017

(c) Author(s) 2017. CC-BY 3.0 License.

The simulated meteorological conditions - at least for the investigated air temperature, wind speed and incoming shortwave radiation - appear to be rather homogeneous over the GrIS, whereas apparent differences between the stations can be explained by their geographical location, i.e. latitude and longitude, as well as elevation.

Snow cover simulations were conducted with the 1-D physically based snow cover model SOWPACK. For this study, we used

5 SNOWPACK in 'research' mode. This version was originally developed and calibrated for avalanche warning applications in Alpine terrain (Lehning et al., 1999). Nevertheless, SNOWPACK simulations using constant densities for new snow ranging from 300 to $350 \mathrm{~kg} \mathrm{~m}^{-3}$ were found to be in good agreement with the observed (SMP) mean density of the upper snow cover. However, the snow cover stratigraphy could not be reproduced by SNOWPACK, showing a lack of understanding of the fundamental processes of the formation and evolution of snow cover on the GrIS. The formation of sastrugi, snow dunes or hardening of the surface layer due to saltation are local effects. Currently, these effects cannot be modeled with a 1-D snow cover model and are also poorly understood. In fact, the differences found between the measured and reanalysis weather data did not significantly affect the modeled snowpack stratigraphy.

The simulated snow accumulation depth at 6 stations with reference to a buried melt-freeze crust, resulting from the 2012 melt event, was found to be in reasonable agreement with the observations; however, deviations of up to $0.7 \mathrm{~m}$ were identified.

15 These deviations could be the result of an underestimation of settling or an overestimation of precipitation - respectively, new snow amounts, or that the 'melt-freeze crust' was formed by preferential infiltration below the July 2012 snow surface. Rapid and deeper infiltration is a well-known phenomenon in subfreezing snow (Tseng et al., 1994).

The SSA was measured using IceCube and a systematic difference of SSA was found when compared with the simulations. Whether this systematic underestimation of about $5 \mathrm{~m}^{2} \mathrm{~kg}^{-1}$ is a result of an insufficient modeling of the snow microstructure or a measuring error of IceCube remains unknown. However, the analysis of snow samples taken at the same location with regard to the SSA using micro-CT showed a better agreement with the simulations. The reason for the deviation between the SSA derived from micro-CT and IceCube might be that the samples used were very hard and extremely small, broken snow particles artificially increased the reflectivity and, hence, the SSA. However, this point must be further investigated.

\section{Conclusions}

25 Meteorological reanalysis data (NHM-SMAP) were used to force the snow cover model SNOWPACK at 14 locations (GCNet) across the GrIS.

NHM-SMAP meteorological parameters, air temperature, wind speed and incoming shortwave radiation were found to be in fair agreement with the observations (GC-Net). The yearly precipitation amounts, maximum wind speed and also the incoming shortwave radiation showed an increasing trend with decreasing latitude. Simulated air temperature and wind speed seem to be homogenous across the GrIS and the average properties can be parameterized by latitude and altitude.

The SNOWPACK simulations were compared to measured data obtained during a field campaign in May 2015. Beside standard manual profiles, the measurements included high-resolution profiles of density and SSA of the upper snow cover 
The Cryosphere Discuss., doi:10.5194/tc-2017-55, 2017

Manuscript under review for journal The Cryosphere

Discussion started: 3 May 2017

(c) Author(s) 2017. CC-BY 3.0 License.

derived from the SMP and IceCube, respectively. A good agreement between the average measured (SMP) and simulated (SNOWPACK) density was found by nudging fixed 'new snow' densities ranging between 300 and $350 \mathrm{~kg} \mathrm{~m}^{-3}$ depending on the geographical location. The simulated SSA showed a systematic offset of about $5 \mathrm{~m}^{2} \mathrm{~kg}^{-1}$ compared to the IceCube measurements. The simulated SSA at Summit was in good agreement with the measurements derived from micro-CT.

5 Although the mean density was in good agreement with the simulations, the observed snow cover stratigraphy (density and SSA) was not reproduced by the simulations.

The accumulated depth of snow since the 2012 melt event was found to be in fair agreement with observations, although deviations of up to $0.7 \mathrm{~m}$ were observed for some stations (MAE $=0.29 \mathrm{~m}$ ). However, it is not completely clear if the "melt layer' represents the surface of the July 2012 snowpack or is a deeper-lying, refrozen, partially water-saturated layer. We conclude that the simulation of the detailed stratigraphy and evolution of the past and future snowpack of the GrIS is an unsolved problem with the used simulation model.

\section{Acknowledgements}

We thank Lino Schmid for help in measuring the snow profiles. For fruitful discussions on SNOWPACK modeling the authors would like to thank Dr. Charles Fierz and Dr. Mathias Bavay. The field research was supported by NASA's Cryospheric

15 Sciences Program, and the Division of Polar Program of the US National Science Foundation. M. Niwano was supported in part by the Japan Society for the Promotion of Science (JSPS), Grant-in-Aid for Scientific Research (A), No. 16H01772 (SIGMA project) and No. 15H01733 (SACURA project), the Global Change Observation Mission - Climate (GCOM-C) / the Second-Generation Global Imager (SGLI) Mission, the Japan Aerospace Exploration Agency (JAXA), the Experimental Research Fund for Global Environment Conservation, the Ministry of the Environment of Japan, and the Grant for Joint Research Program, the Institute of Low Temperature Science, Hokkaido University.

\section{References}

Avanzi, F., G. Petrucci, M. Matzl, M. Schneebeli, and C. De Michele (2017), Early formation of preferential flow in a homogeneous snowpack observed by micro-CT, Water Resour. Res., doi:10.1002/2016WR019502.

Bartelt, P., and Lehning, M., 2002. A physical SNOWPACK model for the Swiss avalanche warning; Part I: numerical model.

25 Cold Reg. Sci. Technol., 35 (3), 123-145.

Benson, C. S. (1960), Stratigraphic studies in the snow and firn of the Greenland ice sheet. Dissertation (Ph.D.), California Institute of Technology. http://resolver.caltech.edu/CaltechETD:etd-03232006-104828.

Box, J.E. and Steffen, K., 2000. Greenland Climate Network (GC-Net): Data Reference. Available at http://cires1.colorado.edu/steffen/gcnet/. 
The Cryosphere Discuss., doi:10.5194/tc-2017-55, 2017

Manuscript under review for journal The Cryosphere

Discussion started: 3 May 2017

(c) Author(s) 2017. CC-BY 3.0 License.

Box, J. E., X. Fettweis, J. C. Stroeve, M. Tedesco, D. K. Hall, and K. Steffen (2012), Greenland ice sheet albedo feedback: Thermodynamics and atmospheric drivers, Cryosphere, 6(4), 821-839, doi:10.5194/tc-6-821-2012.

Brun, E., Martin, E., Simon, V., Gendre, C. and Coleou, C., 1989. An energy and mass model of snowcover suitable for operational avalanche forecasting. J. Glaciol. 35, 333-342.

5 Brun, E., David, P., Sudul, M. and Brugnot, G., 1992. A numerical model to simulate snowcover stratigraphy for operational avalanche forecasting. J. Glaciol. 38, 13-22.

Conger, S. M. and McClung, D., 2009: Instruments and Methods: Comparison of density cutters for snow profile observations, J. Glaciol., 55, 163-169, doi:10.3189/002214309788609038.

Cullen, N.J., and Steffen, K., 2001. Unstable Near-Surface Boundary Conditions in Summer on Top of the Greenland Ice

10 Sheet. Geophys. Res. Lett., 28(23), 4491-4493.

Fettweis, X., et al., 2007. Reconstruction of the 1979-2006 Greenland ice sheet surface mass balance using the regional climate model MAR. The Cryosphere, 1, 21-40, doi:10.5194/tc-1-21-2007.

Franco, B., Fettweis, X., Lang, C., and Erpicum, M., 2012. Impact of spatial resolution on the modelling of the Greenland ice sheet surface mass balance between 1990-2010, using the regional climate model MAR, The Cryosphere, 6, 695-711, doi:10.5194/tc-6-695-2012.

Gallet, J. C., Domine, F., Zender, C. S. and Picard, G., 2009. Measurement of the specific surface area of snow using infrared reflectance in an integrating sphere at 1310 and 1550nm. The Cryosphere, 3, 167-182. doi: 10.5194/tc-3-167- 2009.

Gergely, M.; Wolfsperger, F.; Schneebeli, M. Simulation and Validation of the InfraSnow: An Instrument to Measure Snow Optically Equivalent Grain Size. IEEE Trans. Geosci. Remote Sens. 2014, 52, 4236-4247, doi: 10.1109/TGRS.2013.2280502.

Groot-Zwaaftink, C. D., A. Cagnati, A. Crepaz, C. Fierz, G. Macelloni, M. Valt, and Lehning, M., 2013. Event-driven deposition of snow on the Antarctic Plateau: Analyzing field measurements with SNOWPACK. Cryosphere, 7(1), 333-347, doi:10.5194/tc-7-333-2013.

Hashimoto, A., Niwano, M., Aoki, T., Tsutaki, S., Sugiyama, S., Yamasaki, T., Iizuka, Y., Matoba, S., 2017 Numerical weather prediction system based on JMA-NHM for field observation campaigns on the Greenland ice sheet. Low Temperature Science, in press.

IPCC, 2014: Climate Change 2014: Synthesis Report. Contribution of Working Groups I, II and III to the Fifth Assessment Report of the Intergovernmental Panel on Climate Change [Core Writing Team, R.K. Pachauri and L.A. Meyer (eds.)]. IPCC, Geneva, Switzerland, p 151.

Kobayashi, S., Ota, Y., Harada, Y., Ebita, A., Moriya, M., Onoda, H., Onogi, K., Kamahori, H., Kobayashi, C., Endo, H.,

30 Miyaoka, K., Takahashi, K., 2015. The JRA-55 reanalysis: General specifications and basic characteristics. J. Meteorol. Soc. Jpn., 93, doi:10.2151/jmsj.2015-001.

Lehning, M., Bartelt, P., Brown, R.L., Russi, T., Stöckli, U. and Zimmerli, M., 1999. Snowpack model calculations for avalanche warning based upon a new network of weather and snow stations. Cold Reg. Sci. Technol., 30(1-3): 145-157. 
The Cryosphere Discuss., doi:10.5194/tc-2017-55, 2017

Manuscript under review for journal The Cryosphere

Discussion started: 3 May 2017

(c) Author(s) 2017. CC-BY 3.0 License.

Lehning, M., Bartelt, P., Brown, R.L. and Fierz, C., 2002a. A physical SNOWPACK model for the Swiss avalanche warning; Part III: meteorological forcing, thin layer formation and evaluation. Cold Reg. Sci. Technol., 35 (3), 169-184.

Lehning, M., Bartelt, P., Brown, R.L., Fierz, C. and Satyawali, P.K., 2002b. A physical SNOWPACK model for the Swiss avalanche warning; Part II. Snow microstructure. Cold Reg. Sci. Technol., 35 (3), 147-167.

5 Nghiem, S. V., Hall, D. K., Mote, T. L., Tedesco, M., Albert, M. R., Keegan, K., Shuman, C. A., DiGirolamo, N. E., and Neuman, G., 2012. The Extreme Melt across the Greenland Ice Sheet in 2012. Geophys. Res. Lett., 39, L20502, doi:10.1029/2012GL053611

Niwano, M., Aoki, T., Kuchiki, K., Hosaka, M., and Kodama, Y., 2012. Snow Metamorphism and Albedo Process (SMAP) model for climate studies: Model validation using meteorological and snow impurity data measured at Sapporo, Japan, J.

10 Geophys. Res., 117, F03008, doi:10.1029/2011JF002239.

Niwano M. et al., 2015. Numerical simulation of extreme snowmelt observed at the SIGMA-A site, northwest Greenland, during summer 2012. The Cryosphere 9, doi:10.5194/tc-9-971-2015, 971-988.

Orsi, A. J., K. Kawamura, V. Masson-Delmotte, X. Fettweis, J. E. Box, D. Dahl-Jensen, G. D. Clow, A. Landais, and J. P. Severinghaus (2017), The recent warming trend in North Greenland, Geophys. Res. Lett., doi:10.1002/2016GL072212.

15 Proksch, M., Löwe, H., and Schneebeli, M., 2015. Density, specific surface area, and correlation length of snow measured by high- resolution penetrometry. J. Geophys. Res.-Earth, 120, 346-362, doi:10.1002/2014JF003266.

Proksch, M., Rutter, N., Fierz, C., and Schneebeli, M., 2016. Intercomparison of snow density measurements: bias, precision, and vertical resolution. The Cryosphere, 10, 371-384, doi:10.5194/tc- 10-371-2016.

Saito, K., Fujita, T., Yamada, Y., Ishida, J., Kumagai, Y., Aranami, K., Ohmori, S., Nagasawa, R., Kumagai, S., Muroi, C.,

20 Kato, T., Eito, H., and Yamazaki, Y., 2006. The operational JMA nonhydrostatic mesoscale model, Mon. Weather Rev., 134, 1266-1298, doi:10.1175/MWR3120.1.

Tseng, P.-H., T. H. Illangasekare, and M. F. Meier (1994), Modeling of snow melting and uniform wetting front migration in a layered subfreezing snowpack, Water Resour. Res., 30(8), 2363-2376, doi:10.1029/94WR00764.

Rignot, E., and P. Kanagaratnam, 2006: Changes in the velocity structure of the Greenland Ice Sheet. Science, 311, 986-990.

25 Schmucki, E.; Marty, C.; Fierz, C.; Lehning, M., 2014: Evaluation of modelled snow depth and snow water equivalent at three contrasting sites in Switzerland using SNOWPACK simulations driven by different meteorological data input. Cold Reg. Sci. Technol. 99: 27-37.

Schneebeli, M. and Johnson, J., 1998. A constant-speed penetrometer for high-resolution snow stratigraphy. Ann. Glaciol., 26, $107-111$.

30 Shepherd, A., et al., 2012: A reconciled estimate of ice-sheet mass balance. Science, 338, 1183-1189.

Steffen, K. and J. E. Box, Surface climatology of the Greenland ice sheet: Greenland Climate Network 1995-1999. J. Geophys. Res., 106(D24), 33951-33964, 2001.

Tedesco M, Fettweis X, Mote T, Wahr J, Alexander P, et al., 2012. Evidence and analysis of 2012 Greenland records from spaceborne observations, a regional climate model and reanalysis data. The Cryosphere, 6, 4939-4976. 
The Cryosphere Discuss., doi:10.5194/tc-2017-55, 2017

Manuscript under review for journal The Cryosphere

Discussion started: 3 May 2017

(c) Author(s) 2017. CC-BY 3.0 License.

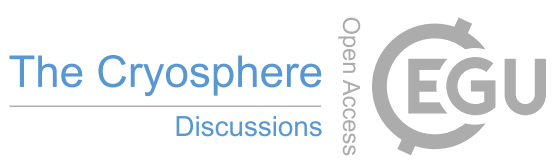

(c) (i)

van den Broeke, M., et al., 2009. Partitioning recent Greenland mass loss. Science 326, 984. doi:10.1126/science.1178176.

Van Meijgaard, E., van Ulft, L. H., Van de Berg, W. J., Bosveld, F. C., Van den Hurk, B., Lenderink, G., and Siebesma, A.

P., 2008. The KNMI regional atmospheric climate model RACMO version 2.1, Tech. Rep. 302, Royal Netherlands Meteorological Institute, De Bilt.

5 Van Tricht, K. et al., 2016. Clouds enhance Greenland ice sheet meltwater runoff. Nat. Commun. 7:10266 doi: $10.1038 /$ ncomms 10266 .

Vionnet, V., E. Brun, S. Morin, a. Boone, S. Faroux, P. Le Moigne, E. Martin, and J.-M. Willemet (2012), The detailed snowpack scheme Crocus and its implementation in SURFEX v7.2. Geosci. Model Dev., 5(3), 773-791, doi:10.5194/gmd-5773-2012.

10 Wever, N., L. Schmid, A. Heilig, O. Eisen, C. Fierz, and M. Lehning (2015), Verification of the multi-layer SNOWPACK model with different water transport schemes. Cryosphere, 9(6), 2271-2293, doi:10.5194/tc-9-2271-2015. 
The Cryosphere Discuss., doi:10.5194/tc-2017-55, 2017

Manuscript under review for journal The Cryosphere

Discussion started: 3 May 2017

(c) Author(s) 2017. CC-BY 3.0 License.

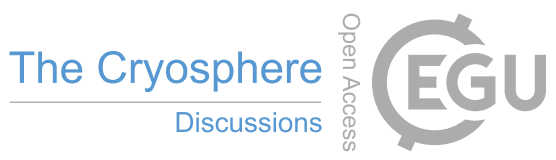

(c) (i)

Tables:

Table 1: Summary statistics for NHM-SMAP grid point locations, i.e. latitude, longitude and elevation, as well as simulated precipitation sums per year and maxima between July 2012 and July 2015. The stations are ordered by decreasing latitude, i.e. north to south.

\begin{tabular}{|c|c|c|c|c|c|c|}
\hline \multirow[b]{2}{*}{ ID } & \multirow[b]{2}{*}{ Name } & \multicolumn{3}{|c|}{ Location } & \multicolumn{2}{|c|}{ Precipitation } \\
\hline & & $\begin{array}{l}\text { Latitude } \\
\circ(\mathrm{N})\end{array}$ & $\begin{array}{l}\text { Longitude } \\
\circ(\mathrm{W})\end{array}$ & $\begin{array}{c}\text { Elevation } \\
\text { m }\end{array}$ & $\begin{array}{l}\text { Sum } \\
\mathrm{mm} \mathrm{y}^{-1}\end{array}$ & $\begin{array}{l}\text { Max. } \\
\mathrm{mm}\end{array}$ \\
\hline 1 & Humboldt & 78.53 & 56.83 & 1995 & 200.4 & 5.7 \\
\hline 2 & Tunu_N & 78.02 & 33.99 & 2113 & 72.5 & 3.7 \\
\hline 3 & NEEM & 77.41 & 51.13 & 2476 & 278.7 & 4.8 \\
\hline 4 & TRV_1 & 77.16 & 48.16 & 2622 & 200.4 & 2.8 \\
\hline 5 & GITS & 77.14 & 61.04 & 1887 & 528.7 & 11.2 \\
\hline 6 & EGRIP & 75.61 & 35.93 & 2718 & 89.1 & 2.1 \\
\hline 7 & NASA_E & 75 & 30 & 2631 & 69.4 & 2.1 \\
\hline 8 & NASA_U & 73.84 & 49.5 & 2369 & 377.4 & 7.4 \\
\hline 9 & Summit & 72.58 & 38.5 & 3254 & 191.8 & 3.1 \\
\hline 10 & Crawford_Point1 & 69.88 & 46.99 & 2022 & 613.4 & 9.3 \\
\hline 11 & Swiss_Camp & 69.57 & 49.32 & 1149 & 940.3 & 25.6 \\
\hline 12 & NASA_SE & 66.48 & 42.5 & 2425 & 936.0 & 9.4 \\
\hline 13 & Saddle & 66 & 44.5 & 2559 & 701.9 & 9.0 \\
\hline 14 & S_Dome & 63.15 & 44.82 & 2922 & 1144.5 & 15.2 \\
\hline
\end{tabular}


The Cryosphere Discuss., doi:10.5194/tc-2017-55, 2017

Manuscript under review for journal The Cryosphere

Discussion started: 3 May 2017

(c) Author(s) 2017. CC-BY 3.0 License.

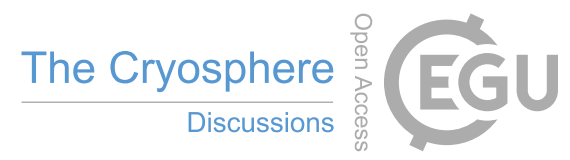

(c) $\underset{\mathrm{BY}}{(i)}$

Figures

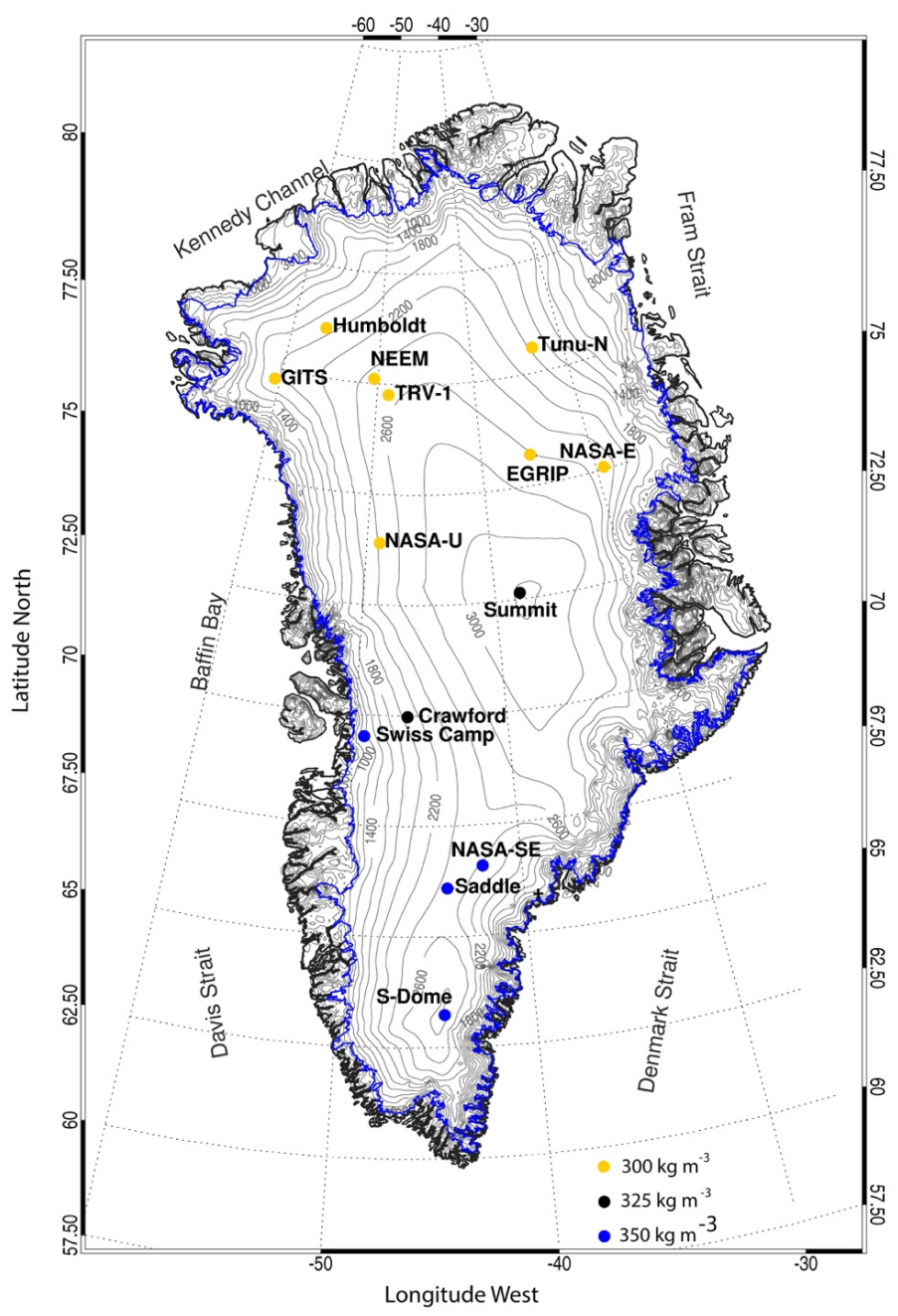

Figure 1: Map of Greenland showing the locations of the NHM-SMAP grid points. Different colors correspond to different fixed new snow densities as used for NHM-SNOWPACK simulations. 
The Cryosphere Discuss., doi:10.5194/tc-2017-55, 2017

Manuscript under review for journal The Cryosphere

Discussion started: 3 May 2017

(c) Author(s) 2017. CC-BY 3.0 License.

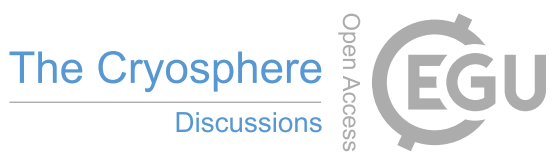

(c) (i)

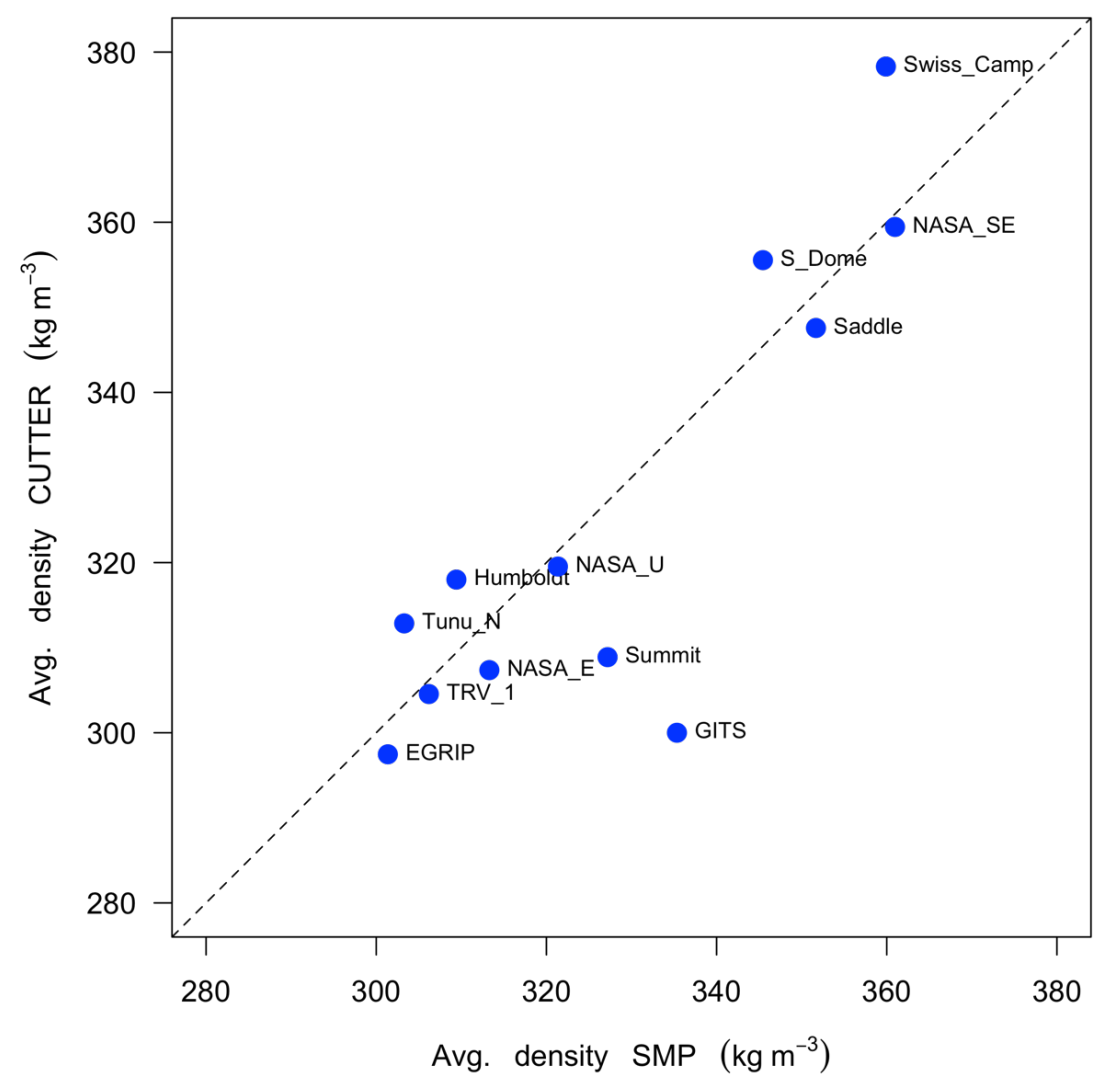

Figure 2: Comparison of averaged density derived from the SMP signal and measured with the density cutter at 12 locations across the GrIS in May 2015. The dashed line shows the one-to-one relationship. 
The Cryosphere Discuss., doi:10.5194/tc-2017-55, 2017

Manuscript under review for journal The Cryosphere

Discussion started: 3 May 2017

(c) Author(s) 2017. CC-BY 3.0 License.
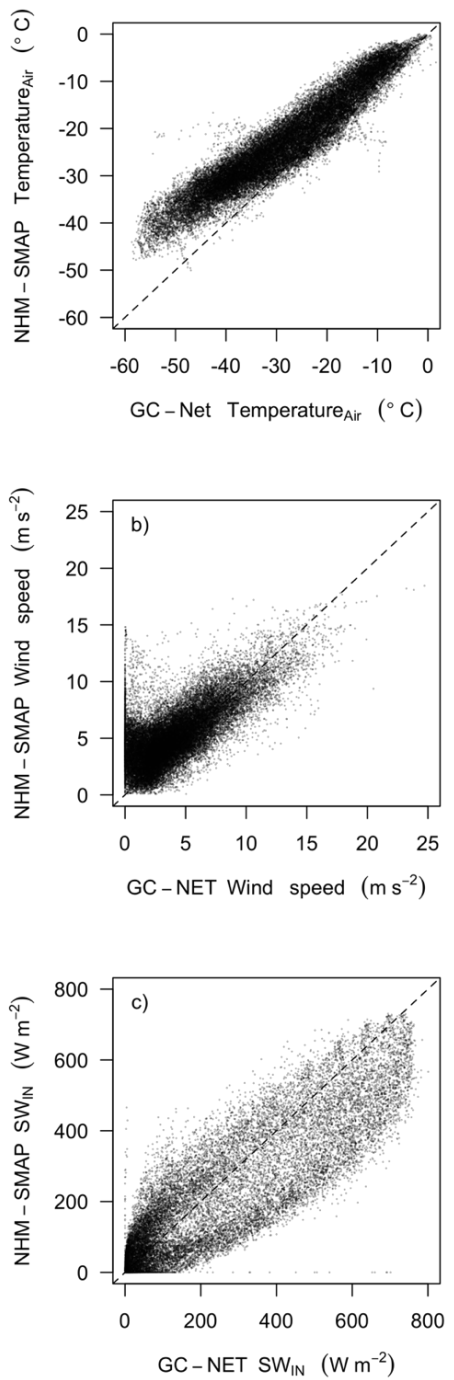

Figure 3: Comparison of measured (GC-Net) and simulated (NHM-SMAP) (a) air temperature (2 m), (b) wind speed and (c) incoming shortwave radiation for Summit station. The dashed line shows the one-to-one relationship. 
The Cryosphere Discuss., doi:10.5194/tc-2017-55, 2017

Manuscript under review for journal The Cryosphere

Discussion started: 3 May 2017

(c) Author(s) 2017. CC-BY 3.0 License.

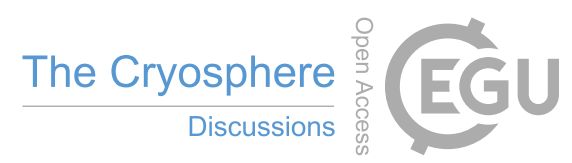

(c) (i)
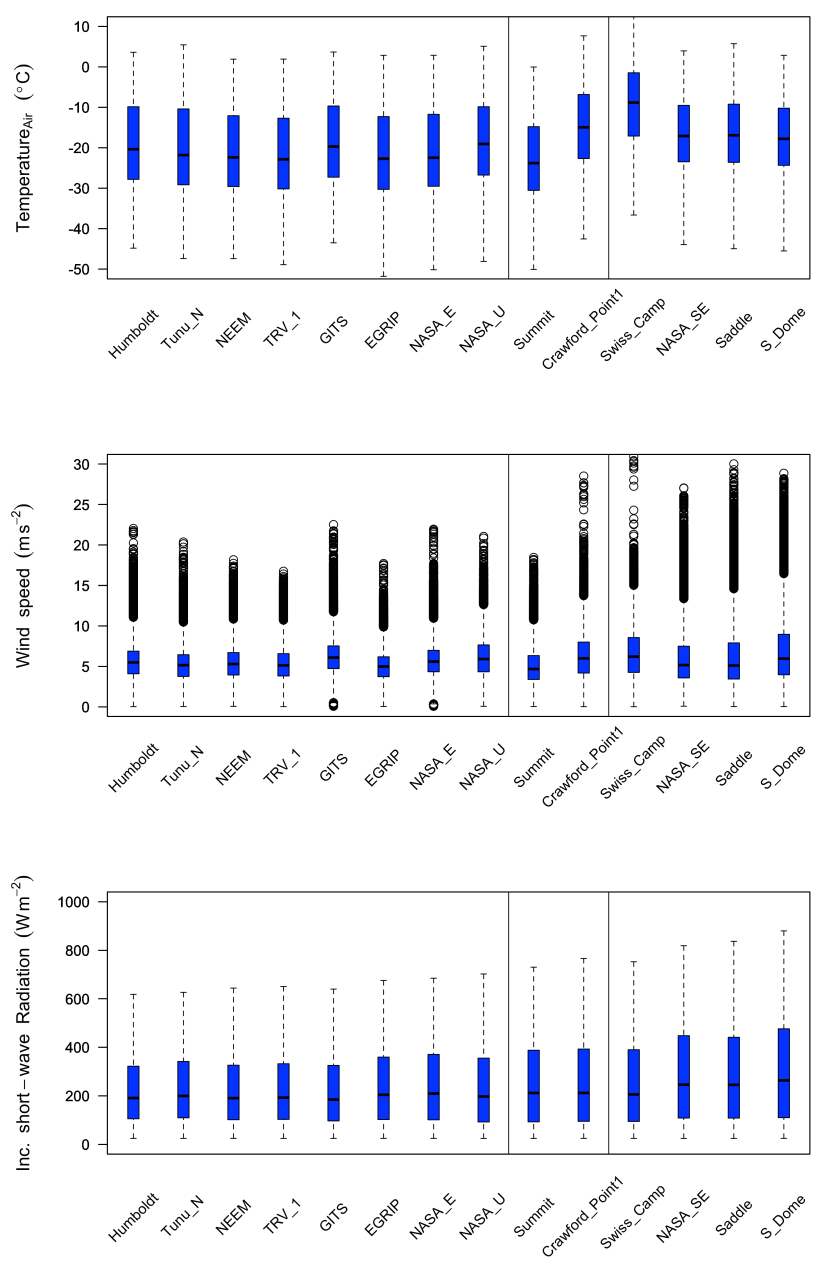

Figure 4: Boxplots of NHM-SMAP air temperature (top), wind speed (middle) and incoming shortwave radiation (bottom) for 14 stations across the GrIS. Note that stations are sorted by decreasing latitude (left to right). Vertical lines separate grid points where a fixed density of $300 \mathrm{~kg} \mathrm{~m}^{-3}, 325 \mathrm{~kg} \mathrm{~m}^{-3}$ or $350 \mathrm{~kg} \mathrm{~m}^{-3}$ was used (left to right). 
The Cryosphere Discuss., doi:10.5194/tc-2017-55, 2017

Manuscript under review for journal The Cryosphere

Discussion started: 3 May 2017

(c) Author(s) 2017. CC-BY 3.0 License.

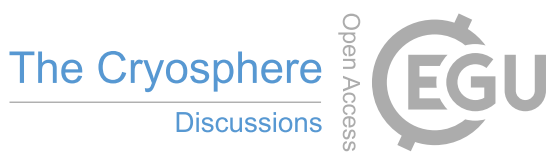

(c) (i)

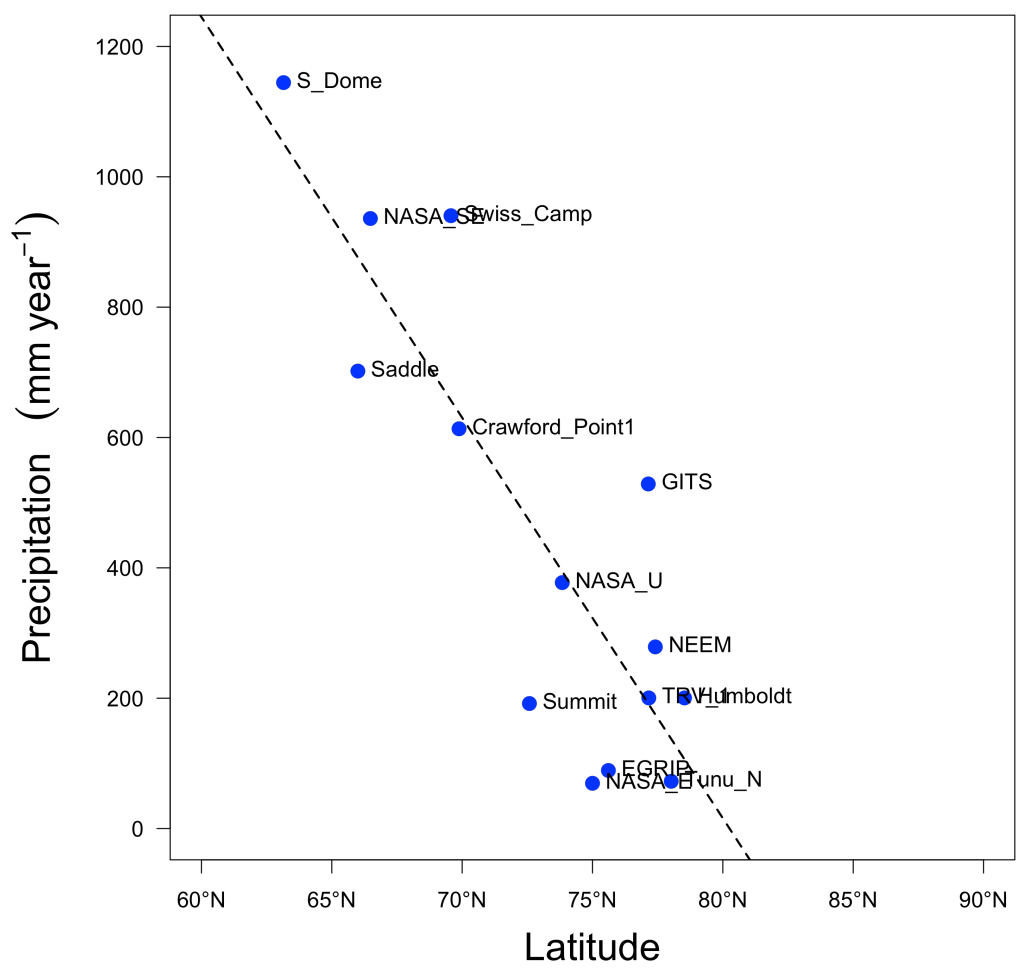

Figure 5: Yearly precipitation sums from NHM-SMAP between July 2012 and July 2015 with latitude. The dashed line shows the results of a simple linear regression. 
The Cryosphere Discuss., doi:10.5194/tc-2017-55, 2017

Manuscript under review for journal The Cryosphere

Discussion started: 3 May 2017

(c) Author(s) 2017. CC-BY 3.0 License.

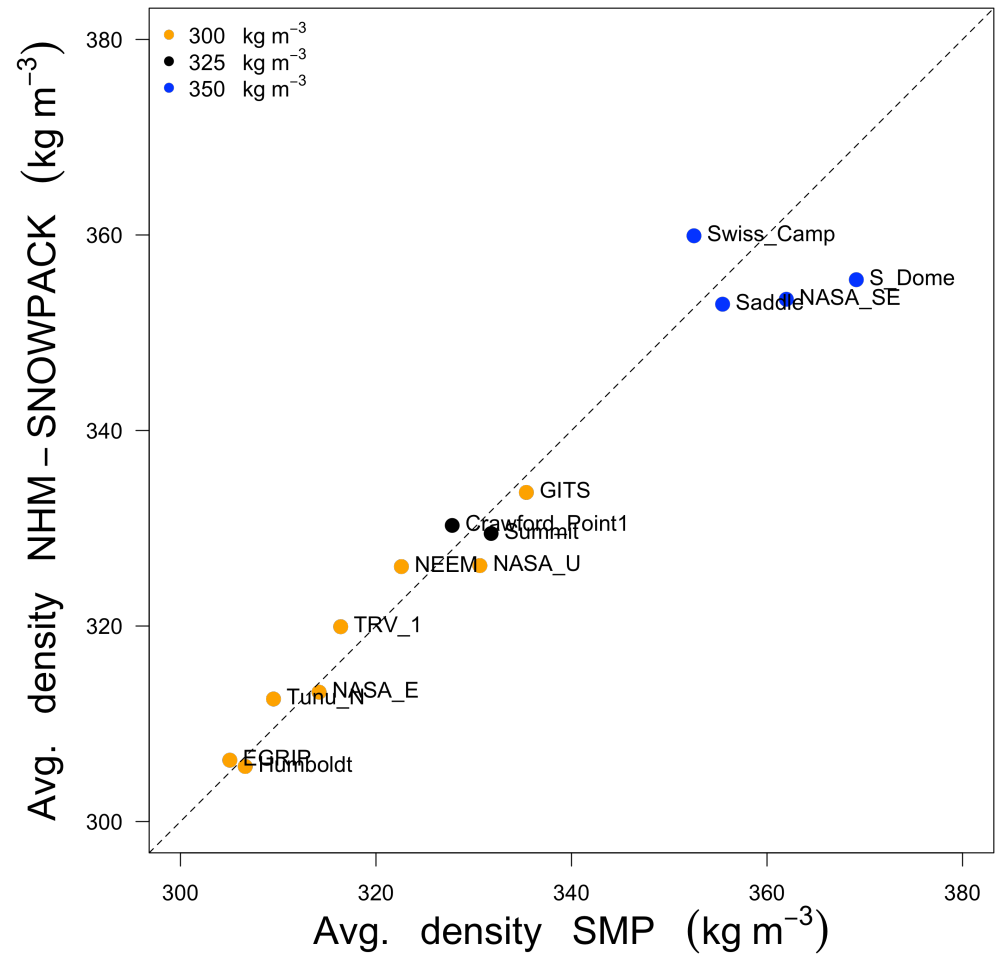

Figure 6: Comparison of the measured (SMP) and simulated (NHM-SNOWPACK) average density for 14 locations across the GrIS. Colors indicate simulation with different fixed new snow densities of $300 \mathrm{~kg} \mathrm{~m}^{-3}$ (blue), $325 \mathrm{~kg} \mathrm{~m}^{-3}$ (green) and $350 \mathrm{~kg} \mathrm{~m}^{-3}$ (orange). The dashed line shows the one-to-one relationship. 
The Cryosphere Discuss., doi:10.5194/tc-2017-55, 2017

Manuscript under review for journal The Cryosphere

Discussion started: 3 May 2017

(c) Author(s) 2017. CC-BY 3.0 License.

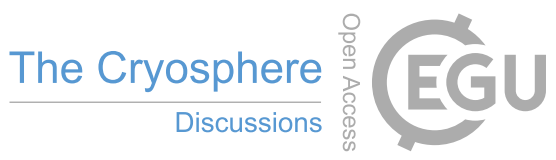

(c) (i)

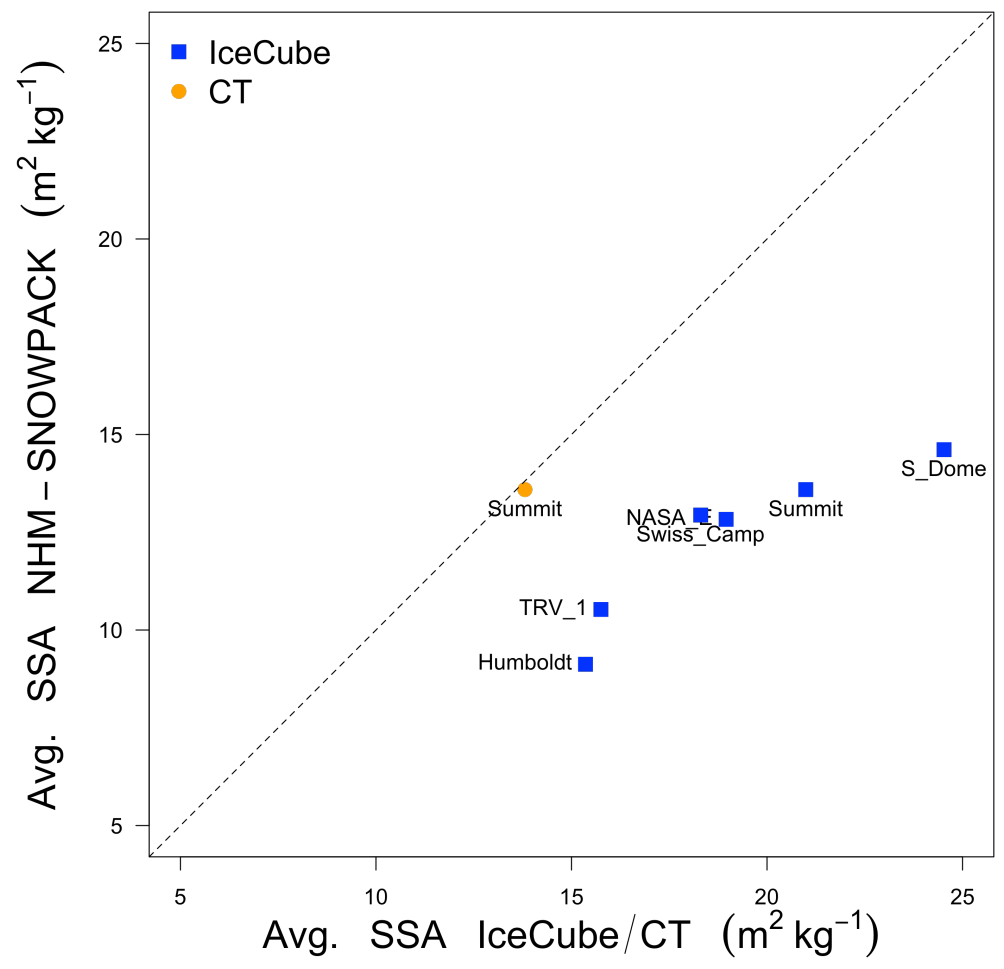

Figure 7: Comparison of measured (IceCube, blue squares) SSA with the corresponding simulations (NHM-SNOWPACK). The filled circle (orange) shows the SSA derived from snow samples analyzed with CT for a single location (Summit). 
The Cryosphere Discuss., doi:10.5194/tc-2017-55, 2017

Manuscript under review for journal The Cryosphere

Discussion started: 3 May 2017

(c) Author(s) 2017. CC-BY 3.0 License.

\section{(c) (i)}
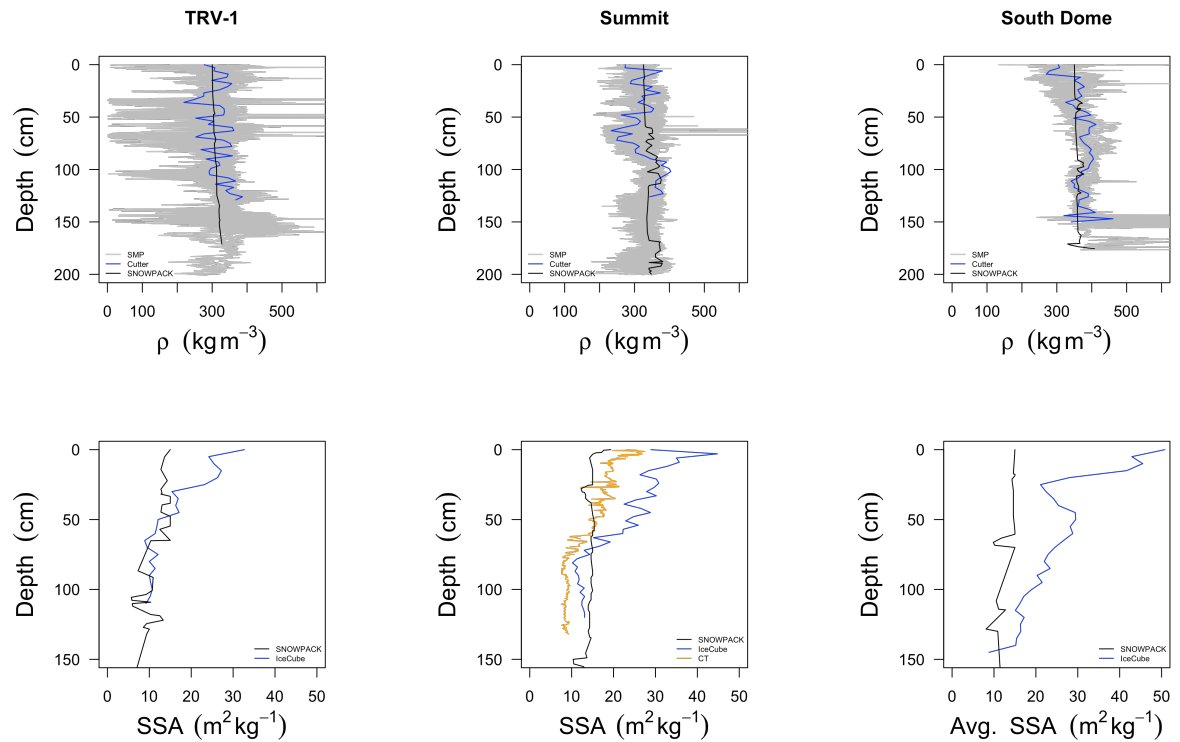

Figure 8: Comparison of measured density top with the SMP (gray) and the density cutter (blue) as well as a comparison of measured SSA (IceCube, CT; bottom) with corresponding NHM-SNOWPACK simulations (black) for TRV-1, Summit and South Dome, respectively. Note that multiple SMP measurements were taken at the corresponding locations. SSA measured by CT (orange) was only available for Summit. 
The Cryosphere Discuss., doi:10.5194/tc-2017-55, 2017

Manuscript under review for journal The Cryosphere

Discussion started: 3 May 2017

(c) Author(s) 2017. CC-BY 3.0 License.

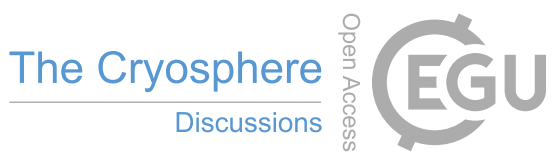

(c) (i)

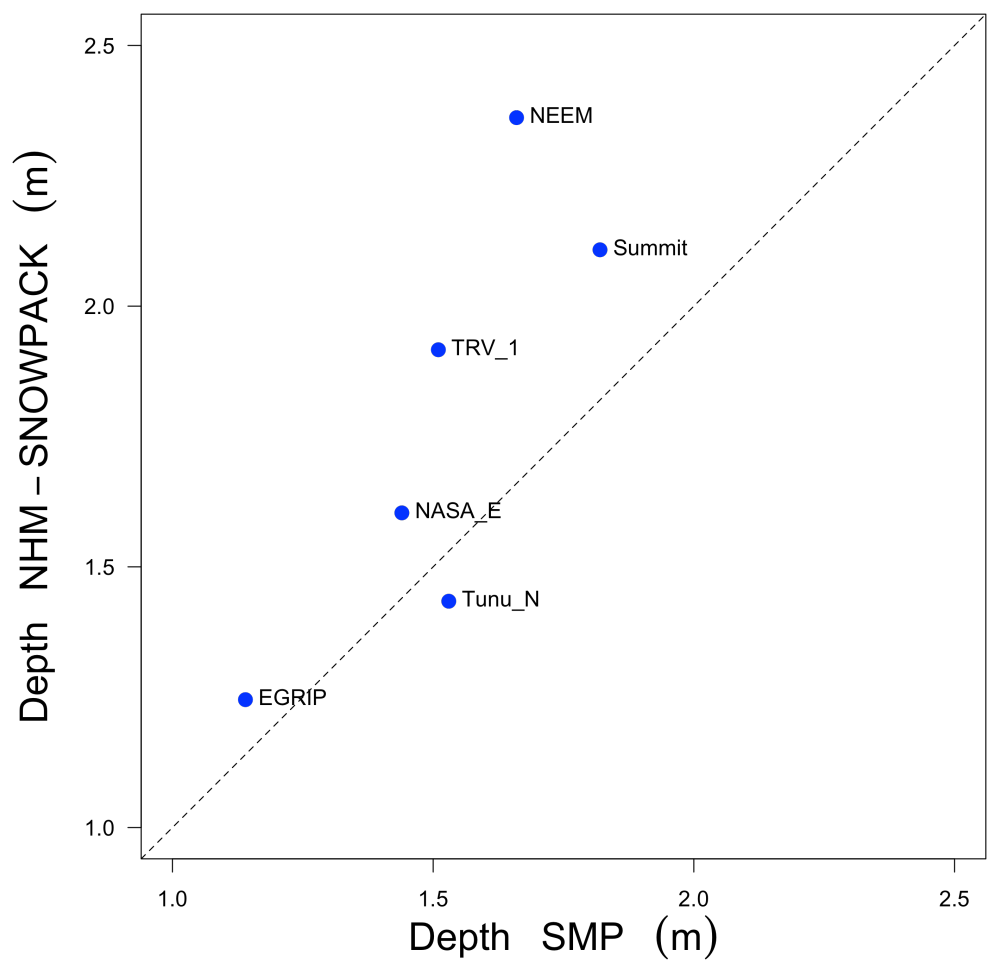

Figure 9: Comparison of measured (SMP) and simulated depth (NHM-SNOWPACK) of the 2012 melt layer for 6 locations across the GrIS. 